\title{
FAKTOR OBESITAS DAN KOLESTEROL TERHADAP HIPERTENSI DI INDONESIA (INDONESIAN FAMILY LIFE SURVEY V)
}

\section{Obesity and Cholesterol Factors on Hypertension In Indonesia (Data of Indonesian Family Life Survey $V$ )}

\author{
Purwo Setiyo Nugroho* ${ }^{1}$, Denny Saptono Fahrurodzi ${ }^{2,3}$ \\ 1. Program Studi Kesehatan Masyarakat, Universitas Muhammadiyah Kalimantan Timur, Indonesia \\ 2. Departemen Epidemiologi Fakultas Kesehatan Masyarakat Universitas Indonesia , Indonesia \\ ${ }^{3 .}$ Master Student at University of Debrecen, Hungary
}

Diterima: 07 Desember 2018; Revisi: 12 Desember 2018; Diterbitkan: 28 Desember 2018

\section{Abstract}

Background \& Objective: Hypertension is a threatening health problem that can be found almost in the community. Indonesia is a developing country that contributes in the rate of hypertension, it is noted that the age of 18 years and over the prevalence of hypertension in Indonesia is $31.7 \%$, with these problems, researchers will examine the factors associated with the incidence of hypertension in Indonesia. Material and Methods: This study is a secondary data analysis with the design of Cross Sectional and uses Chi Square analysis. The respondents of this study amounted to 30133 who had been separated from the complete data. Results: Most of the respondents were female (53.1\%); and $<40$ years old (59.3\%; not obese $(78.3 \%)$; having low cholesterol levels $(99.2 \%)$; not hypertension $(92.1 \%)$. Bivariate analysis found a correlation between cholesterol levels (p value 0,000; OR 4,450; CI 95\% 3,329 - 5,984) and obesity (p value 0,000; OR 4,348; CI 95\% 3,991-4,738) towards hypertension. Conclusion: Among the two variables studied (cholesterol and obesity), cholesterol level is a variable the most likely risk for hypertension

Keywords: Obesity, Cholesterol, Hypertension

\section{Abstrak}

Latar Belakang \& Tujuan : Hipertensi merupakan sebuah masalah kesehatan yang mengancam hampir dapat ditemukan di tengah masyarakat. Indonesia merupakan negara berkembang yang ikut andil dalam menyumbang angka hipertensi, tercatat bahwa usia 18 tahun keatas prevalensi hipertensi di Indonesia sebesar 31,7\%, dengan adanya permasalahan tersebut, peneliti akan meneliti faktor yang berkaitan dengan kejadian hipertensi di Indonesia. Bahan dan Metode : Penelitian ini adalah analisis data sekunder dengan desain penelitian ini adalah Cross Sectional serta menggunakan analisis Chi Square. Responden penelitian ini berjumlah 30133 yang telah dipilah dari kelengkapan datanya. Hasil : Sebagian besar responden berjenis kelamin perempuan (53,1\%); dan berumur $<40$ tahun $(59,3 \%)$; tidak obesitas (78,3\%); memiliki kadar kolesterol rendah (99,2\%); tidak hipertensi (92,1\%). Analisis bivariat mendapatkan ada hubungan antara kadar kolesterol ( $p$ value 0,000; OR 4,450; CI 95\% 3,329 - 5,984) dan obesitas (p value 0,000; OR 4,348; CI 95\% 3,991-4,738) terhadap hipertensi. Kesimpulan : Diantara dua variabel yang diteliti (kolesterol dan obesitas), kadar koleterol merupakan variabel yang paling berpeluang berisiko untuk terjadinya hipertensi.

Kata Kunci: Obesitas, Kolesterol, Hipertensi

*Korespondensi: Telp: +6285736362626, Email :purwo.skm@umkt.ac.id

\section{PENDAHULUAN}

Hipertensi merupakan sebuah masalah kesehatan yang mengancam hampir dapat ditemukan di tengah masyarakat, penyakit ini memiliki risiko dapat meningkat pada setiap tahunnya (Hafid, 2012). Hipertensi dapat memicu penyakit lainnya seperti stroke, penyakit jantung koroner, gagal jantung dan ginjal (Sudarsono E K R., 2017).

Menurut WHO (World Health Organization Re- gional Office for South-East Asia, 2011), pada tahun 2009 sekitar 972 jiwa penduduk di dunia menderita hipertensi dengan persentase pada pria sebesar $26,6 \%$, sedangkan pada wanita sebesar $26,1 \%$.

Insiden penyakit hipertensi di negara maju sebesar 333 juta dan 639 juta di negara berkembang termasuk Indonesia(Sulastri \& Rahmi Ramadhani, 2012) .

Indonesia merupakan negara berkembang yang ikut andil dalam menyumbang angka hipertensi, tercatat - 
bahwa usia 18 tahun keatas prevalensi hipertensi di Indonesia sebesar $31,7 \%$, serta sebanyak $7,2 \%$ dari penderita hipertensi mengetahui tentang sakitnya dan hanya $0,4 \%$ kasus yang minum obat hipertensi. Diperkirakan $6 \%$ penyebab kematian di dunia disebabkan karena hipertensi(Akbar, 2013). Hipertensi disebabkan oleh banyak faktor yang dapat di modifikasi dan tidak dapat di modifikasi (Herwati \& Wiwi sartika, 2014). Salah satu faktor yang dapat dimodifikasi adalah obesitas dan kadar kolesterol dalam tubuh.

Obesitas merupakan faktor risiko yang penentuannya menggunakan Indeks Massa Tubuh (IMT). Penggunaan IMT hanya berlaku pada orang dewasa diatas 18 tahun, IMT tidak cocok untuk mengukur obesitas pada anak-anak, bayi, remaja dan olahragawan. Hipertensi memiliki kaitan dengan adanya peningkatab berat badan dan hal ini merupakan hal penting dalam mekanisme timbulnya hipertensi pada orang yang obesitas(Dien, Mulyadi; \& Kundre, 2014). Angka obesitas di Indonesia terus meningkat, hal ini dikarenakan perubahan pola gaya hidup yang cenderung bermalas malasan beraktivitas dan menjamurnya makanan junkfood di Indonesia. Obesitas merupakan salah satu penyumbang terjadinya penyakit tidak menular di Indonesia yang angkanya pun terus meningkat. Salah satu penyakit tidak menular tersebut adalah hipertensi, berdasarkan Case Fatality Rate, hipertensi pada tahun 2008 sebesar 2,84\% dengan jumlah kasus 198.180 kasus, pada tahun 2009 CFR hipertensi sebesar 2,55\% dengan jumlah kasus 136.677 kasus dan pada tahun 2010 mengalami peningkatan menjadi 4,81\% dengan jumlah kasus 277.845 kasus (Indah \& Ningrum, 2015).

Penyebab hipertensi juga dikarenakan makanan yang banyak mengandung kolesterol, protein dan garam tinggi namun rendah serat pangan. Kolesterol merupakan keluarga lemak, zat ini merupakan salah satu dari komponen lemak itu sendiri (Al-rahmad \& Fadjri, 2016).

Kehadiran lemak ini sesungguhnya memiliki fungsi sebagai zat gizi yang sangat diperlukan oleh tubuh disamping zat gizi lainnya seperti karbohidrat, protein, vitamin dan mineral (Feryadi, Sulastri, \& Kadri, 2014). Dalam fungsinya dalam tubuh, kolesterol yang berlebih akan menyebabkan menempel dalam pembuluh darah sehingga menyebabkan plak yang akan berisiko terjadinya hipertensi (Nuriska \& Saraswati, 2011). Kolesterol merupakan zat yang banyak terkadung pada orang dengan obesitas, sehingga antara obesitas dan kolesterol ini berkaitan yang dapat menjadikan risiko terjadinya hipertensi pada setiap individu (Weni et al., 2015).

Terus bertambahnya angka hipertensi di Indonesia, maka peneliti akan meneliti faktor yang berkaitan dengan hpertensi di Indonesia. Dalam penelitian ini, peneliti memfokuskan faktor obesitas dan kolesterol yang berkaitan secara biologis dan menjadi risiko terjadinya hipertensi.

\section{BAHAN DAN METODE}

\subsection{Jenis Penelitian}

Jenis penelitian ini adalah penelitian data sekunder yang bersumber dari data survei Indonesian Family Life Survey $V$ di Indonesia. Penelitian ini berfifat kuantitatif dimana interpretasinya berdasarkan olahan statistik yang dibantu menggunakan aplikasi komputer.

\subsection{Desain Penelitian}

Penelitian ini merupakan penelitian sekunder yang menganalisis lanjut data Indonesian Familit Life Survey $V$ tahun 2014. Desain penelitian yang digunakan adalah Cross Sectional, dimana desain penelitian ini melihat variabel bebas dan variabel terikat hanya pada penelitian saja, sehingga sering disebut dengan penelitian satu waktu.

\subsection{Sampel}

Jumlah sampel pada penelitian ini berjumlah 30133 yang berumur $\geq 15$ tahun. Jumlah ini didapatkan dari pemilihan responden yang sesuai dengan kriteria, salah satunya adalah responden yang terbebas dari missing data

\subsection{Kriteria}

Penelitian ini merupakan penelitian data sekunder dimana kriteria yang diambil menyesuaikan data yang telah tersedia. Atas pertimbangan peneliti, maka responden yang diambil (kriteria inklusi) hanyalah responden yang menjawab lengkap dan tidak memiliki missing data yang terdapat pada dataset. Adapun responden yang memiliki missing data akan dihapus dan tidak diikutkan dalam penelitian (kriteria enklusi) yakni responden yang dibawah umur 15 tahun yang memang tidak diukur variabel penelitian.

\subsection{Sumber Data}

Sumber data pada peneltian menggunakan data sekunder ini dengan cara mendownload data sekunder dari penyedia data yang dapat diakses pada link https:// www.rand.org/labor/FLS/IFLS/download.html. Data tersebut dikumpulkan oleh organisasi RAND Coorporation.

\subsection{Metode Pengumpulan dan Pengolahan Data}

Data yang didapat dikelola dengan menggunakan tools Select Cases pada aplikasi komputer, dimana data yang dianalisis hanyalah data yang sesuai dengan kriteria inklusi penelitian saja. Selain itu dengan menghapus beberapa responden yang memang tidak dapat dianalisis dikarenakan data yang missing .

\subsection{Analisis Data}

Analisis data dalam penelitian ini adalah Chi Square yang menghubungkan antar 2 variabel untuk mendapatkan nilai risiko pada tiap hubungan. Selain itu, analisis ini juga dapat melihat kesignifikasian penelitian dan sifat dari hubungan 2 variabel melalui nilai rentang Confidence Interval .

\section{HASIL}

Analisis yang dilakukan dalam penelitian ini adalah univariat dan bivariat dimana terdapat dua variabel bebas (kolesterol dan Obesitas) yang dikaitkan dengan variabel terikat (hipertensi). 
Tabel 1 menjelaskan tentang deskriptif individu penelitian, hasil analisis dapat disimpulkan bahwa sebagiab besar responden berjenis kelamin perempuan $(53,1 \%)$; dan berumur $<40$ tahun $(59,3 \%)$; tidak obesitas (78,3\%); memiliki kadar kolesterol rendah (99,2\%); tidak hipertensi $(92,1 \%)$;

Tabel 2 menyatakan bahwa hasil ada hubungan yang hubungan antara kadar kolesterol dengan hipertensi ( $p$ value 0,000; OR 4,450; CI 95\% 3,329 5,984). Artinya, orang yang memiliki kadar kolesterol tinggi memiliki peluang risiko terjadinya hipertensi sebesar 4,450 kali dibandingka orang yang memiliki kadar kolesterol rendah.

Tabel 3 menyatakan bahwa hasil ada hubungan yang hubungan antara status obesitas dengan hipertensi ( $\mathrm{p}$ value 0,000; OR 4,348; CI 95\% 3,9914,738). Artinya, orang yang memiliki obesitas memiliki peluang risiko terjadinya hipertensi sebesar 4,348 kali dibandingka orang yang tidak obesitas.

\section{PEMBAHASAN}

Pada umumnya, penderita hipertensi merupakan orang-orang yang memiliki kadar kolesterol dalam tubuh yang cukup tinggi. Hal ini dikarenakan kolesterol merupakan lemak dalam tubuh yang

\section{Tabel 1. Karakteristik Responden Penelitian}

\begin{tabular}{lll}
\hline Variabel & $\mathbf{n}$ & $\mathbf{\%}$ \\
\hline Jenis kelamin & & \\
$\quad$ Laki-laki & 14118 & 46,9 \\
$\quad$ Perempuan & 16015 & 53,1 \\
Umur & & \\
$\quad>40$ Tahun & 12275 & 40,7 \\
$\quad<40$ Tahun & 17858 & 59,3 \\
Status Obesitas & & \\
$\quad$ Obesitas & 6536 & 21,7 \\
$\quad$ Tidak obesitas & 23597 & 78,3 \\
Kolesterol & & \\
$\quad$ Kadar tinggi & 236 & 0,8 \\
$\quad$ Kadar rendah & 29897 & 99,2 \\
Hipertensi & & \\
$\quad$ Hipertensi & 2371 & 7,9 \\
$\quad$ Tidak hipertensi & 27762 & 92,1 \\
\hline
\end{tabular}

memiliki peluang untuk mengendap dalam pembuluh darah sehingga dapat menyebabkan hipertensi pada individu (Sartik, RM. Suryadi Tjekyan, 2017).

Kolesterol yang tinggi biasanya disebabkan oleh konsumsi makanan yang rendah serat dan berminyak.

Makan makanan jenis ini berpeluang untuk terjadinya obesitas pada individu, sehingga obesitas memiliki kaitannya dengan hipertensi yang terjadi.

Obesitas yang berkaitan dengan hipertensi diperkuan oleh penelitian oleh Febby Haendra Dwi Anggara dkk pada tahun 2012 di Cikarang Jawa Barat yang menyatakan bahwa ada hubungan yang signifikan ( $p$-value 0,000) antara obesitas dengan hipertensi (Anggara, D.H.F., \& Prayitno, 2013) Hal ini sejalan dengan penelitian yang dilakukan oleh Sumardiyono dkk yang menyatakan bahwa ada hubungan antara obesitas dengan hipertensi ( $p$ value $0,000)$. Penelitian tersebut juga menyatakan bahwa orang yang obesitas/ gemuk memiliki risiko mengalami hipertensi 6 kali dibandingkan orang/ responden yang normal/ kurus. Penelitian tersebut dilakukan pada pekerja yang terpapar bising melebihi NAB (Sumardiyono, Ada, Wijayanti, \& Rinawati, 2015). Orang yang memiliki obesitas akan membutuhkan banyak darah untuk menyuplai oksigen dan makanan ke jaringan tubuhnya, sehingga volume darah yang beredar melalui pembuluh darah juga meningkat(Dien et al., 2014) .

Hal ini menyebabkan curah jantung ikut meningkat dan akhirnya tekanan darah ikut meningkat. Selain itu, dengan meningkatnya obesitas ini, maka akan mempengaruhi kadar insulin dalam darah, peningkatan isulin ini menyebabkan resistensi natrium pada ginjalm sehingga tekanan darah ikut naik(Sulastri \& Rahmi Ramadhani, 2012).

Pada penelitian ini juga di analisis terkait hubungan kadar kolesterol dengan hipertesi, hasilnya ada hubungan antara kedua variabel tersebut ( $p$ value $0,000)$.

Orang yang memiliki kadar kolesterol tinggi memiliki peluang risiko 4,450 kali (CI 95\% 3,329 5,984 ) untuk terjadinya hiperteni dibandingkan orang yang kadar kolesterolnya rendah. Kolesterol tinggi (hiperkolesterolemia) akan menimbulkan masalah

Tabel 2 Hubungan Kadar Kolesterol Terhadap Hipertensi

\begin{tabular}{lllll}
\hline Variabel & Hipertensi & Tidak Hipertensi & p-value & OR (CI 95\%) \\
\hline Kolesterol Tinggi & 64 & 172 & 0,000 & $4,450(3,329-5,948)$ \\
Kolesterol Rendah & 2307 & 27590 & & \\
\hline
\end{tabular}

Tabel 3 Hubungan Status Obesitas Terhadap Hipertensi

\begin{tabular}{lllll}
\hline Variabel & Hipertensi & Tidak Hipertensi & p-value & OR (CI 95\%) \\
\hline Obesitas & 1205 & 5331 & 0,000 & $4,348(3,991-4,738)$ \\
Tidak Obesitas & 1166 & 22431 & & \\
\hline
\end{tabular}


terutama pada pembuluh darah dan otak. Jika kadar kolesterol melebihi batas normal akan menyebabkan aterosklerosis.

Aterosklerosis akan menyumbah pembuluh darah arteri dan dinding - dinding pada saluran arteri yang mengalami arterosklerosisakan menjadi tebal, kaku karena tumpukan kolesterol, saluran arteri mengalami proses penyempitan, pengerasan, kehilangan kelenturannya dan menjadi kaku. Hal ini sejalan dengan penelitian yang dilakukan oleh Heni Maryanti tahun 2017 yang menyatakan ada hubungan yang tinggi antara kadar kolesterol dengan tekanan darah pada penderita hipertensi di Dusun Rejomulyo Desa Rejoagung (Maryati, 2017).

Jika kadar kolesterol melebihi batas normal, akan menyebabkan aterosklerosis. Aterosklerosis ini akan menyumbat pembuluh darah arteri (Nuriska \& Saraswati, 2011). Dinding-dinding pada saluran arteri yang mengalami aterosklerosis akan menjadi tebal dan kaku dikarenakan penumpukan kolesterol. Saluran arteri akan mengalami proses penyempitan, pengerasan serta kehilangan kelenturannya.Apabila sel-sel otot arteri ini mengali gangguan tersebut, maka akan terjadi penyakit seperti hipertensi, aritmia, stroke dan lain lain (Maryati, 2017).

\section{KESIMPULAN}

Obesitas dan kadar kolesterol tinggi memiliki hubungan dengan kejadian hipertensi di Indonesia berdasarkan data survei Indonesian Family Life Survey $V$. Berdasarkan analisis Chi Square pada penelitian ini, kadar kolesterol yang tinggi memiliki risiko yang lebih besar untuk terjadinya hipertensi dibandingkan dengan besarnya risiko pada obesitas, dimana nilai Odds Ratio pada kadar kolesterol sebesar 4,450 CI 95\% 3,329 5,948, sedangkan pada obesitas memiliki nilai Odds Ratio sebesar 4,348, CI 95\% 3,991-4,738.

\section{DAFTAR PUSTAKA}

Akbar, N. (2013). Pengaruh Bekam Basah Terhadap Kolesterol dan Tekanan Darah pada Pasien Hipertensi di Semarang. Media Medika Muda. Retrieved from http://www.ejournals1.undip.ac.id/index.php/medico/article/ view/4956

Al-rahmad, A. H., \& Fadjri, T. K. (2016). Faktor Resiko Peningkatan Kolesterol pada Usia Diatas 30 Tahun di Kota Banda Aceh. Jurnal Nutrisia, 18 (2), 109-114.

Anggara, D.H.F., \& Prayitno, N. (2013). Faktor-Faktor Yang Berhubungan Dengan Tekanan Darah di Puskesmas Telaga Murni Cikarang Barat Tahun 2012. Jurnal Ilmiah Kesehatan, volume 5(1), 20 -25 .

Dien, N. G., Mulyadi;, \& Kundre, R. M. (2014). Hubungan Indeks Massa Tubuh (IMT) dengan Tekanan Darah pada Penderita Hipertensi di Poliklinik Hipertensi dan Nefrologi BLU RSUP Prof. DR. R. D. Kandou Manado. Jurnal Keperawatan, 09(2), 7. https://doi.org/10.1111
Feryadi, R., Sulastri, D., \& Kadri, H. (2014). Hubungan Kadar Profil Lipid dengan Kejadian Hipertensi pada Masyarakat Etnik Minangkabau di Kota Padang Tahun 2012. Jurnal Kesehatan Andalas, 3 (2), 206-211. https://doi.org/10.1144/ gsl.sp.2004.238.01.04

Hafid, M. (2012). Hubungan Riwayat Hipertensi Dengan Kejadian Stroke Di Rsup Dr. Wahidin Sudirohusodo Makassar 2012. Kesehatan, VII(1), 6.

Herwati, \& Wiwi sartika. (2014). Terkontrolnya Tekanan Darah Penderita Hipertensi Berdasarkan Pola Diet dan Kebiasaan Olahraga di adang Tahun 2011, Jurnal Kesehatan Masyarakat 8(1), 814.

Indah, D. T., \& Ningrum, D. N. A. (2015). Evaluasi Input Sistem Survailans Hipertensi Di Wilayah Kerja Dinas Kesehatan Kota Magelang Berdasarkan Pedoman Sistem Surveilans Penyakit Tidak Menular. Unnes Journal of Public Health,4(2), 92 -99. Retrieved from http://journal.unnes.ac.id/

Maryati, H. (2017). Hubungan Kadar Kolesterol Dengan Tekanan Darah Kabupaten Jombang, Jurnal Keperawatan, 8, 128-137.

Nuriska, A. . S. I., \& Saraswati, M. R. (2011). Hubungan Kadar Kolesterol Total Dengan Hipertensi Sistolik Pada Pasien Diabetes Melitus Tipe 2 Di Poliklinik Endokrin Rumah Sakit Umum Sanglah Periode Januari-Desember 2011.E-Jurnal Medika Udayana, 4 (1). 2015. ISSN 2303-1395

Sartik, RM. Suryadi Tjekyan, M. Z. (2017). Faktor Faktor Risiko dan Angka Kejadian Hipertensi Pada Penduduk Palembang, Jurnal Ilmu Kesehatan Masyarakat 8 (3), 180-191. https://doi.org/ doi.org/10.26553/jikm.2017.8.3.180-191

Sudarsono E K R., S. J. F. A. dkk. (2017). Peningkatan Pengetahuan tentang Hipertensi Guna Perbaikan Tekanan Darah pada Anak Muda di Dusun Japanan, Margodadi, Sayegan, Sleman, Yogyakarta. Jurnal Pengabdian Kepada Masyarakat, Vol. 3, No. 1, September 2017, 3 (1), 26-38. https:// doi.org/DOI: jpkm. 25944

Sulastri, D., \& Rahmi Ramadhani. (2012). Hubungan Obesitas dengan Kejadian Hipertensi pada Masyarakat Etnik Minangkabau di Kota Padang. Majalah Kedokteran Andalas, 36(2), 188-201.

Sumardiyono, Ada, Y. R., Wijayanti, R., \& Rinawati, S. (2015). Pengaruh Indeks Massa Tubuh (Imt) Terhadap Tekanan Darah Pada Pekerja Yang Terpapar Bising Industri Di Surakarta. Seminar Nasional Hasil - Hasil Penelitian Dan Pengabdian LPPM Universitas Muhammadiyah Purwokerto, (September), 43-48.

Weni, K. I. K., Isti, S., Nurul Huda, S., Listiana Purnaning, S., Mahardika Marta, A., Diana, M., \& Sholihah. (2015). Faktor-faktor yang mempengaruhi kejadian obesitas pada remaja. Jurnal Gizi Klinik Indonesia, 11(4), 179-190. 
https://doi.org/10.22146/ijen.22900

World Health Organization Regional Office for SouthEast Asia. (2011). Hypertension fact sheet. $H y$ pertension, 1-2 